\title{
$\mathrm{CCl}_{4}$ INDUCED LIVER INJURY;
}

\section{AQUEOUS EXTRACT OF GINKGO BILOBA (GKBE) AMELIORATES CYTOPLASMIC AND MITOCHONDRIAL ENZYMES}

1. MBBS, M.Phil.

Assistant Professor

Department of Anatomy

Bhitai Dental and Medical College

Mirpurkhas, Sindh, Pakistan.

2. MBBS, M.Phil.

Department of Pathology

Bhitai Dental and Medical College

Mirpurkhas, Sindh, Pakistan.

3. MBBS, M.Phil.

Assistant Professor

Department of Anatomy

Indus Medical College

Tando Muhammad Khan,

Sindh, Pakistan.

Correspondence Address:

Dr Sana Naz

MBBS, M.Phil.

Assistant Professor

Department of Anatomy

Bhitai Dental and Medical College

Mirpurkhas, Sindh, Pakistan.

giggly786@gmail.com

drsanaarain@gmail.com

Article received on:

07/12/2016

Accepted for publication:

10/03/2017

Received after proof reading:

06/05/2017

\section{INTRODUCTION}

Ginkgo biloba, a famous natural herb, is commonly used medicinal remedy. The medicinal use of Ginkgo biloba (Gkb) dates back to centuries since time immemorial. Gkb is recognized because of its efficacy and cure of various diseases over many centuries back. ${ }^{1}$ Biochemical analysis of $\mathrm{Gkb}$ extract (GkbE) shows various ingredients such as kaempferol, isorhamnetin, quercitin and organic acids such as the 4-hydroxybenzoic acid. Gkb contains diterpene lactones include the bilobalide and Ginkgolides (A, B, C, M and J). It also contains biflavones which include the ginkgetin, isoginkgetin, bilobetin. These ingredients are reported of pharmacological efficacy. ${ }^{2,3} \mathrm{GkbE}$ exerts powerful biological anti oxidant activity. Reported therapeutic effects of Gkb include the; anti diabetic potential, cardioprotective effects, neuromodulatory and memory enhancing effects, decrease of mental fatigue, increased physical and mental activity. Clinically, Gkb is now most frequently prescribed herb in neuromedicine practice. ${ }^{4,5} \mathrm{GkbE}$ diminishes the senile cerebral insufficiency. It is prescribed for the treatment of dementia, defective cognition and Alzheimer's type dementia. ${ }^{6}$ GkbE has been reported to augment the inhibition of platelet activation and increased blood flow in vivo studies. GkbE scavenges oxygen derived free radicals and protects the cell injury. GkbE has been used in the cardiac injury, infarction, brain infarction, ischemic reperfusion induced injury. ${ }^{2,7}$ Efficacy against the ethanol induced gastric mucosal injury, ${ }^{8}$ and chemical induced oxidative stress and liver fibrosis have been reported. ${ }^{9}$

Keeping in view the background literature, the protective effect of GkbE against carbon 
tetrachloride injury was revisited. The present study was prospectively planned to observe the mitigating effects of GkbE against the carbon tetrachloride hepatocellular injury. Effects of GkbE against carbon tetrachloride injury were evaluated in terms of both liver enzymes and microscopic examination in experimental rat model.

\section{MATERIALS AND METHODS}

Prior written permission was taken from the ethical review and animal ethics committee. A sample of sixty male Wistar albino rats was obtained. The rats were housed at the Animal house, Bhitai Dental and Medical College Mirpurkhas and Agriculture University Tando Jam from Animal house from May 2015 - August 2016. Male Wistar albino rats of 150- 200 grams were the inclusion criterion. Female rats, sick male rats, and rats feeding not well were excluded from the study protocol. Care was taken of optimal temperature $\left(25^{\circ} \mathrm{C}\right)$ and humidity was maintained at $55-60 \%$. Animals were environmental protected by 12 hour light-dark cycles. Chaw diet was provided ad libitum and clean water was available all the time.

Sixty rats were equally divided into 3 groups

- Group 1-Controls (0.9\% isotonic saline),

- Group 2- $\mathrm{CCl}_{4} 1.0 \mathrm{mg} / \mathrm{kg}$ intraperitoneal and

- Group 3- $\mathrm{CCl}_{4}$ (1.0mg/kg intraperitoneal) and GkbE 50/kg orally)

Treatment was given for 4 weeks consecutively

\section{Aqueous extract of G. biloba (GkbE)}

GkbE was prepared from leaves (100 grams) soaked in approximately 1 liter boiling water. It was homogenized in distilled water. Magnetic stirrer was used for stirring at $40^{\circ} \mathrm{C}$ for 1 hour. The solution was filtered through 2-layer of cheese cloth. $17.561 \mathrm{gm} \mathrm{GkbE}$ was obtained. Residue was re-extracted within the fresh boiling distilled water. Aqueous Gkb was put in rotary evaporator in vacuum. After lyophilization, it was stored at 4 oc. ${ }^{1}$

\section{Carbon tetrachloride (CCl4) and Induction of DM}

Purchase of $\mathrm{CCl}_{4}$ (Sigma Chemical Co. St. Louis, $\mathrm{MO}$, USA) was ordered from scientific drug store, sponsored in Pakistan by Biodiagnostic Co. Analytical grading of chemical was checked for high laboratory purity. $\mathrm{CCl}_{4} 1 \mathrm{mg} / \mathrm{kg}$ b.w was administered intraperitoneal for induction of diabetes mellitus. ${ }^{10}$

\section{Animal sacrifice}

Rats were sacrificed by cervical dislocation (Ketamine and Xylazil) as per Nayak et al. ${ }^{11}$

\section{Estimation of liver enzymes}

Blood samples were collected at end of experiment from tail veins. Blood was centrifuged at $3000 \mathrm{rpm}$ for 10 minute time period to separate sera. Liver enzymes were estimated on Roche Hitachi Chemistry analyzer.

\section{Liver tissue processing}

Tissue was fixed in formaldehyde (10\%) and embedded after in paraffin. Tissue was processed according to standard procedure. Microscopic study of $3 \mu$ tissue sections was observed after $\mathrm{H}$ \& E staining. Histological liver injury was graded as; $0=$ no abnormal findings observed, $+1=$ mild injury observed, +2 moderate injury observed and +3 severe injury observed. ${ }^{12}$

\section{Data analysis}

Data was analyzed on Statistix 10.0 (USA) at 95\% confidence interval $(P \leq 0.05)$. Continuous variables were analyzed by ANOVA and post Hoc Duncan test and results were presented as mean \pm SD. Categorical variables were analyzed by Chi-square test.

\section{RESULT}

The GkbE significantly mitigated the $\mathrm{CCl}_{4}$ induced hepatocellular injury as observed by improvement in the liver aminotransferases (ALT, AST, ALP), serum GGT and LDH $(p=0.001)$. Group 2 rats treated with $\mathrm{CCl}_{4}$ showed severe hepatocellular injury as marked rise in liver enzymes was noted. The liver enzymes in Group $3\left(\mathrm{CCl}_{4}\right.$ $+\mathrm{GkbE}$ ) showed significant decrease in liver aminotransferase and liver histology $(p=0.001)$. The GkbE treated rats showed a decrease in hepatocyte cytoplasmic enzymes (e.g. ALT) and mitochondrial enzymes (e.g. AST) as shown in Table-I and Figure-1. 
Histological examination of liver tissue (graded as; inflammation, vacuolar degeneration, fatty change, sinusoid congestion and hepatocyte necrosis) was significantly improved by GkbE treatment as shown in Table-II. Histological examination of liver tissue is shown in Figure-1 to 3 respectively. Liver tissue in $\mathrm{CCl}_{4}$ treated rats show severe hepatocellular injury (Figure-2), the tissue details are lost with distortion. $\mathrm{CCl}_{4}$ treated liver tissue reveals inflammatory infiltrates, fatty change, sinusoid congestion, vacuolar degeneration and hepatocyte necrosis (Figure 2). All these destructive changes were mitigated by $\mathrm{GkbE}$ treated rats as shown in Figure-3 $\left(\mathrm{CCl}_{4}+\right.$ GkbE group).

\begin{tabular}{|l|c|c|c|c|c|}
\hline & ALT (iu/L) & AST (iu/L) & LDH (iu/L) & GGT (iu/L) & ALP (iu/L) \\
\hline Group.1. controls & $40.5 \pm 9.2$ & $54.1 \pm 11.5$ & $513.5 \pm 37.5$ & $23.4 \pm 7.5$ & $100.5 \pm 23.0$ \\
\hline Group.2. CCl $_{4}$ & $232.5 \pm 23.7$ & $323.7 \pm 18.5$ & $2058.9 \pm 107.6$ & $158.0 \pm 17.6$ & $214.1 \pm 38.0$ \\
\hline Group.3. $\mathrm{CCl}_{4}+\mathrm{GkbE}$ & $150.9 \pm 21.6$ & $213.5 \pm 21.5$ & $1948.3 \pm 121.5$ & $68.3 \pm 23.5$ & $153.7 \pm 27.1$ \\
\hline P-value & 0.0001 & 0.002 & 0.0001 & 0.003 & 0.0001 \\
\hline & \multicolumn{3}{|c|}{$\mathrm{CCl}_{4}-$ Carbon tetrachloride, GkbE- Ginkgo biloba extract } \\
\hline
\end{tabular}

\begin{tabular}{|l|c|c|c|}
\hline $\begin{array}{l}\text { Histological } \\
\text { Parameter }\end{array}$ & Group 1 & Group 2 & Group 3 \\
\hline Inflammation & 0 & +4 & +3 \\
\hline $\begin{array}{l}\text { Vacuolar } \\
\text { degeneration }\end{array}$ & 0 & +4 & +2 \\
\hline Fatty change & 0 & +4 & +4 \\
\hline $\begin{array}{l}\text { Sinusoid } \\
\text { congestion }\end{array}$ & 0 & +4 & +3 \\
\hline Necrosis & 0 & +4 & +2 \\
\hline $\begin{array}{r}\text { Table-II. Histological grading of liver injury } \\
\text { *Carbon tetrachloride, † Ginkgo biloba extract }\end{array}$ \\
\hline
\end{tabular}

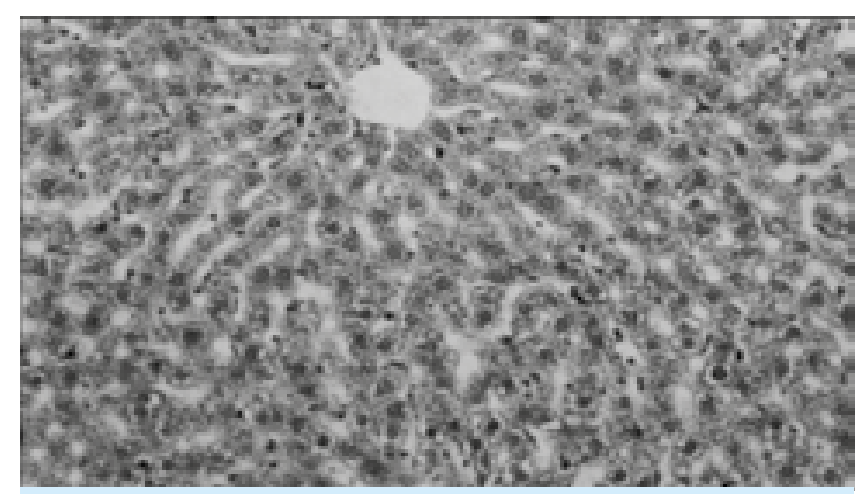

Figure-1. Liver tissue microscopy in control rats (H\& E 40x)

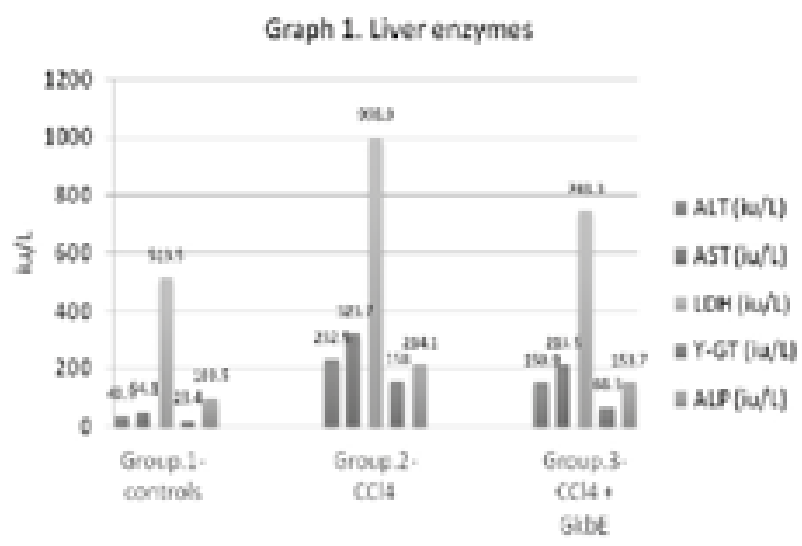

Graph-1. Liver enzymes

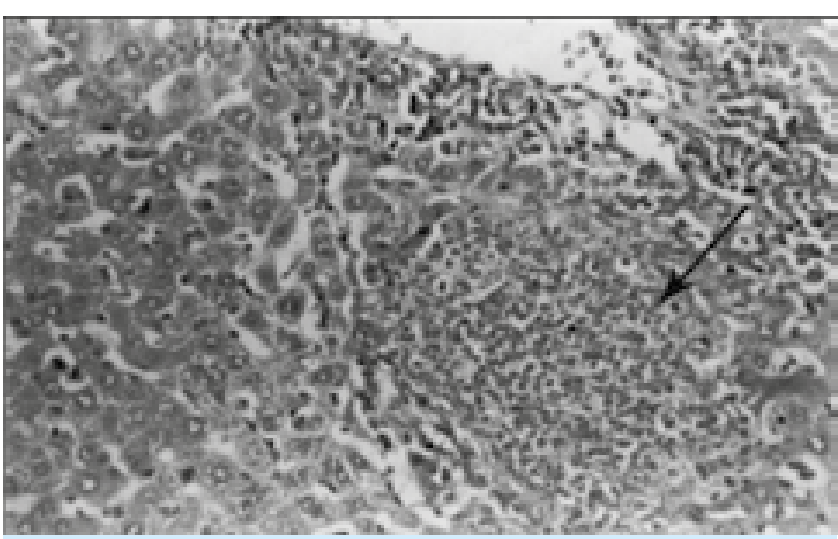

Figure-2. $\mathrm{CCl}_{4}$ treated liver tissue. Microscopy examination reveals severe tissue injury (H\& E 40x)

\section{DISCUSSION}

The present study is the first report on the mitigating effects of aqueous extract of Ginkgo biloba (GkbE) against carbon tetrachloride $\left(\mathrm{CCl}_{4}\right)$ liver injury as indicated by hepatocyte cytoplasmic

and mitochondrial enzymes, and liver histology in albino rat. Drug and chemical induced liver injury is frequently observed in clinical emergency practice and there is need to evaluate easily available herbal remedies. 


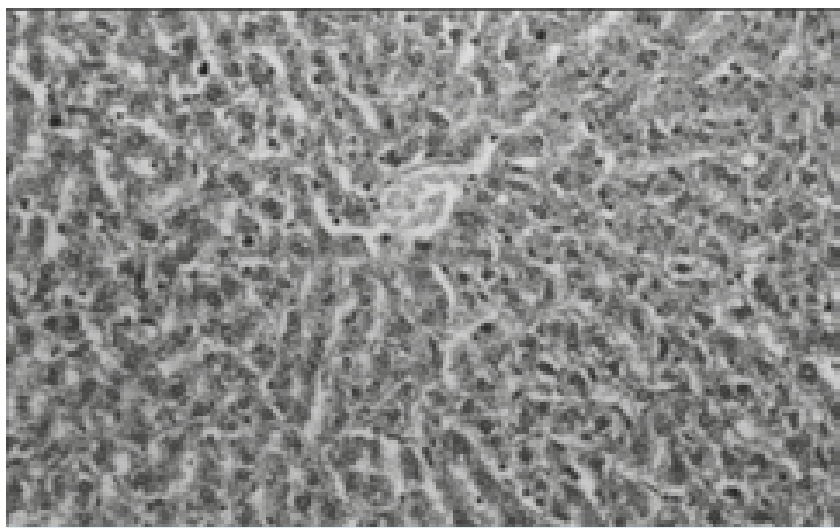

Figure-3. GkbE $+\mathrm{CCl}_{4}$ treated liver tissue. It shows hepatocyte cords

with minimal tissue injury (H\& E 40x)

The GkbE showed significant mitigation of carbon tetrachloride induced chemical injury of liver (Table I and II). GkbE improved both cytoplasmic and mitochondrial enzymes and liver histology. These findings are in agreement with previous study. ${ }^{13}$ They reported similar results of cytoplasmic and mitochondrial enzymes amelioration in $\mathrm{CCl}_{4}$ treated animal model..$^{13}$ In carbon tetrachloride treated group the liver cell cytoplasmic and mitochondrial enzymes were raised because of severe cell membrane and mitochondrial injury mediated by free radicals generated by carbon tetrachloride. ${ }^{14}$ The group 2 animals treated by $\mathrm{CCl}_{4}$ showed similar pattern of liver enzymes as reported by above study, hence the findings are in keeping with. ${ }^{14}$ The $\mathrm{CCl} 4$ induces hepatocyte rupture with release of liver enzymes; AST, ALT, ALP and LDH which are the best markers of cell injury. ${ }^{15,16}$ Alanine transaminase is a surrogate marker of hepatocyte cytoplasmic injury which was raised in present study and findign is in keeping with previous studies. ${ }^{17,18}$

In present study, the GkbE proved of its hepatoprotective potential as it mitigated the liver injury markers and liver histology, the results tally with the previous studies. ${ }^{19-21}$ The underlying mechanism of how GkbE mitigates the cellular injury needs further studies at molecular level. However, the findings of present study support previous studies. ${ }^{1,22,23}$

The experience of $\mathrm{CCl}_{4}$ was very much serious as the rats of group 2 showed seriously rise in liver enzymes compared to control. The $\mathrm{CCl}_{4}$ is proved hepatotoxic agent used in experimental studies, the findings of $\mathrm{CCl}_{4}$ induced liver damage supports the previous studies. ${ }^{24-26}$ AST is a marker of mitochondrial injury which was found elevated in $\mathrm{CCl}_{4}$ treated rats; the finding is in agreement with previous studes. ${ }^{26-28}$ Liver aminotransferases (ALT, AST, ALP), serum GGT and LDH were restored by $\mathrm{GkbE}$ co administration in group $3(p=0.001)$. The present study suggests the GkbE may protect against free radical mediated injury by a direct anti oxidant effect, stabilizing cell and mitochondrial membranes which needs further studies. The findings are in agreement with previous studies. ${ }^{29-32}$ Moreover; a previous study ${ }^{7}$ reported the GkbE protects the vascular endothelial cells and microcirculation also. However, this seems to be not more than a speculation. The present study suggests the GkbE has potential of mitigating the carbon tetrachloride induced chemical injury, and most probably it be having activity against other chemicals and drugs, hence it may be used as herbal remedy for poisoning cases. The GkbE mitigates the carbon tetrachloride induced liver injury and ameliorates the cytoplasmic and mitochondrial enzymes and liver histology. The major limitation of present study is short duration of four weeks, small sample size and molecular phenomena were not evaluated because of non availability of research facilities and funding issues.

\section{CONCULSION}

The present study concludes the Ginkgo biloba (GkbE) has potential of mitigating chemical induced liver injury as carbon tetrachloride $\left(\mathrm{CCl}_{4}\right)$. Ginkgo biloba (GkbE) ameliorated both liver cellular enzymes and liver histology. Ginkgo biloba (GkbE) may be used as an easily available and inexpensive home herbal remedy in cases of chemical and drug induced liver injury.

Copyright(C) 10 Mar, 2017.

\section{REFERENCES}

1. Guo WY, Ni ZJ, Wang ZX, Fu ZR, Li RD. The protective effects of Ginkgo leaf extract on $\mathrm{CCl}_{4}$-induced liver injury in mice. J Medicinal Plants Res 2011; 5(11): 
$2361-4$.

2. Ahlemeyer B, Krieglstein J. Neuroprotective effects of Ginkgo biloba extract. Cell Mol. Life Sci 2003; 60: 1779-92.

3. Boonkaew T, Camper ND. Biological activities of Ginkgo extracts. Phytomedicine 2004; 12: 318-23.

4. Naik SR, Pilgaonkar VW, Panda VS. Neuropharmacological evaluation of Ginkgo biloba phytosomes in rodents. Phytother Res 2006; 20: 9015.

5. Naik SR, Panda VS. Antioxidant and hepatoprotective effects of Ginkgo biloba phytosomes in carbon tetrachloride-induced liver injury in rodents. Liver Int 2007; 27:393-9.

6. Kwon YS, Ann HS, Nabeshima T, Shin EJ, Kim WK, Jhoo $\mathrm{JH}$. Selegiline potentiates the effects of EGb 761 in response to ischemic brain injury. Neurochem. Intl 2004; 45:157-70.

7. Zhang WR, Hayashi T, Kitagawa $\mathrm{H}$. Protective effect of ginkgo extract on rat brain with transient middle cerebral artery occlusion. Neurol Res 2000; 22:51721.

8. Wang $Q$, Zhao WZ, Ma CG. Protective effects of Ginkgo biloba extract on gastric mucosa. Acta Pharm Sin 2000; 21:1153-6.

9. Ding J, Yu J, Wang C, Hu W, Li D, Luo Y. Ginkgo biloba extract alleviates liver fibrosis induced by $\mathrm{CCl} 4$ in rats. Liver Int`I 2005; 25:1224-32.

10. Karthikeyan $M$ and Deepa K. Hepatoprotective effect of Premna corymbosa (Burm. f.) Rottl \& Willd leaves extract on $\mathrm{CCl} 4$ induced hepatic damage in Wistar albino rats. Asian Pacific J Trop Med 2010; 3(1): 17-20.

11. Nayak S, Nalabothu $P$, Sandiford $S$, Bhogadi $V$, and Adogwa A. Evaluation of wound healing activity of Allamanda cathartica L. and Laurus nobilis. L. Extracts on rats. BMC Complementary and Alternative Medicine 2006; 6: 12

12. Murat-Bilgin $H$, Atmaca $M$, Deniz-Obay $B$, Ozekinci $S$, Taşdemir $E$ and Ketani A. Protective effects of coumarin and coumarin derivatives against carbon tetrachloride-induced acute hepatotoxicity in rats. Exp Toxicol Pathol 2011; 63(4): 325-30.

13. Hurkkeri VI, Jaiparkash B, Lavhale RV, Karadi RV and Kuppast IJ. Hepatoprotective activity of Anthus Excelsa Roxb leaf extract on experimental liver damage in rats. J Pharmacogn 2002; 11: 120-28.
14. Shaarawy SM, Tohamy AA, Elgendy SM Elmageed ZY, Bahnasy A, Mohamed MS, et al. Protective effects of garlic and silymarin on NDEA-induced rats hepatotoxicity. Int J Biol Sci 2009; 5(6): 549-57.

15. Rajesh M, Latha M. Preliminary evaluation of antihepatotoxic activity of Kamilari, a polyherbal formulation. J Ethnopharmacol 2004; 91: 99-104.

16. Bashandy S, Al-Wasel S. Carbon tetrachloride-induced hepatotoxicity and nephrotoxicity in rats: Protective role of vitamin C. J Pharm Toxico 2001; 16(30): 283-92.

17. Ravikumar V, Shivashangari K, Devak IT. Hepatoprotective activity of Tridax procumbens against d-galactosamine/lipopolysaccharideinduced hepatitis in rats. J Ethnopharmacol 2005; 101: 55-60.

18. Kumar P, Sivaray A, Elumalai E, Kumar B. Carbon tetrachloride-induced hepatotoxicity in rats protective role of aqueous leaf extracts of Coccinia grandis. Int J Pharm Tech Res 2009; 1(4): 1612-15.

19. Venukumar MR, Latha MS. Hepatoprotective effect of the methanolic extract of Curculigo Orchioides in CCl4-treated male rats. Indian J Pharmacol 2002; 34:269-275.

20. Chang HF, Lin YH, Chu CC, Wu SJ, Tsai YH, Chao JC. Protective effects of Ginkgo biloba, Panax ginseng, and Schizandra chinensis extract on liver injury in rats. Am J Chinese Med 2007; 35 (6): 995-1009.

21. Balamurugan $G$, Muthusamy $P$. Observation of the hepatoprotective and antioxidant activities of Trianthema decandra Linn (Vallai sharunnai) roots on carbon tetrachloride-treated rats. Bangladesh $\mathrm{J}$ Pharmacol 2008; 3(2):83-89.

22. Farooq $S$, Ahmed I, Pathak GK. In vivo protective role of Koflet (an ayurvedic preparation) against cellular toxicity caused by CCl4. J Ethnopharmacol 1997; 58(2):109-16.

23. Dias MC, Rodrigues MAM, Reimberg MCH, Barbisan LF. Protective effects of Ginkgo biloba against rat liver carcinogenesis. Chemico-Biological Interactions 2008; 173:32-42.

24. Tirkey N, Pilkhwal S, Kuhad A, Chopra K. Hesperidin, a citrus bioflavonoid decreases the oxidative stress produced by carbon tetrachloride in rat liver and kidney. BMC Pharmacol 2005; 5(2):1-8.

25. Anand KV, Anandhi R, Pakkiyaraj M, Geraldine P. Protective effect of chrysin on carbon tetrachloride (CCI4) induced tissue injury in male Wistar rats. Toxicol Ind Health 2011; 27(10):923-33. 
26. Drotman RB, Lawhorn GT. Serum enzymes are indicators of chemically induced liver damage. Drug Chem Toxicol 1978; 1(2):163-71.

27. Achliya GS, Kotgale SG, Wadodkar AK, Dorle AK. Hepatoprotective activity of Panchgavya Gritha in carbon tetrachloride induced hepatotoxicity in rats. Indian J Pharmacol 2003; 135:311.

28. Muriel P, Garciapina T, Perez-Alvarez V, Mourelle M. Silymarin protects against paracetamol-induced lipid peroxidation and liver damage. J Appl Toxicol 1992; 12(6):439-42.

29. Thabrew M, Joice PA. A comparative study of the efficacy of Pavetta indica and Osbeckia octanda in the treatment of liver dysfunction. Planta Med 1987; 53(3):239-41.
30. Itil T, Martorano D. Natural substances in psychiatry (Ginkgo biloba in dementia). Psychopharmacol Bull 1995; 31:147-58.

31. Cha'vez-Morales RM, Jaramillo-Jua'rez F, Posadas del RI'o FA, Reyes-Romero MA, Rodri'guez-Va'zquez ML, Martı'nez-Saldan a MC. Protective effect of Ginkgo biloba extract on liver damage by a single dose of CCI4 in male rats. Human Exp Toxicol 2010; 30(3):20916.

32. Suresh Kumar SV, Sujatha C, Syamala J, Nagasudha $\mathrm{B}$, Mishra SH. Hepato-protective activity of extracts from Pergularia daemia Forsk against carbon tetrachloride induced toxicity in rats. Phcog Mag 2007; 3:11.

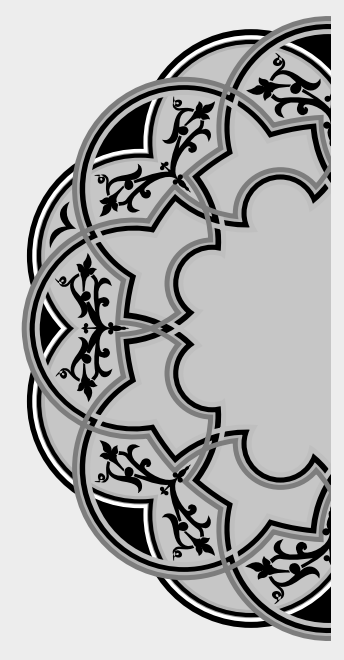

"Life is the most difficult EXAM. Many people fail because they try to copy others. Not realizing that everyone has a different question paper."

Unknown

\section{AUTHORSHIP AND CONTRIBUTION DECLARATION}

\begin{tabular}{|c|l|}
\hline Sr. \# & Author-s Full Nam \\
\hline 1 & Dr. Sana Naz \\
2 & Dr. Faisal Irshad \\
3 & Dr. Hina Mawani \\
\hline
\end{tabular}

Contribution to the paper

Concept of study, data collection, performa designing, Data analysis, manuscript write and proof.

Concept of study, data collection, performa designing.

Concept of study, data collection performat designing, consent form, manuscript write and proof.
Author $=\mathbf{s}$ Signature

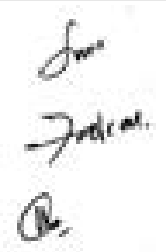

